Sains Malaysiana 50(10)(2021): 2859-2867

http://doi.org/10.17576/jsm-2021-5010-01

\title{
Effect of Larval Food Amount on in vitro Rearing of Indo-Malayan Stingless Bee Queen, Heterotrigona itama (Hymenoptera: Apidae; Meliponini)
}

(Kesan Jumlah Makanan Larva Ternakan in vitro Ratu Kelulut Indo-Malaya, Heterotrigona itama (Hymenoptera:

Apidae; Meliponini))

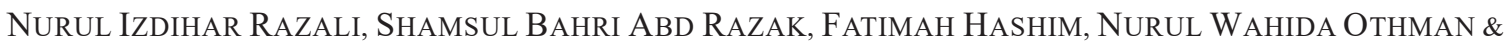 \\ WAHIZATUl AFZAN AZMI*
}

\begin{abstract}
The demand for stingless bee colonies in Malaysia has considerably increased due to the rapid advance of meliponiculture in using the stingless bees as agricultural pollinators, as well as the commercialization of stingless bee products (i.e. honey, bee bread and propolis). Thus, in vitro queen rearing for a large scale and rapid colony multiplication must be developed in order to fulfil the public requirements in a short period. Little is known about the in vitro rearing of native stingless bee queen, Heterotrigona itama. Therefore, in this study, we investigated the amount of larval food required by $\mathrm{H}$. itama queen by comparing three different amounts of larval food, viz., $100 \mu \mathrm{L}, 120 \mu \mathrm{L}$ and $150 \mu \mathrm{L}$. All treatments were controlled under 100\% relative humidity for the first 6 days, and $75 \%$ relative humidity for the rest of larval development until queen adult emergence, under $30^{\circ} \mathrm{C}$ incubator temperature. The results showed that larvae of $\mathrm{H}$. itama treated with the highest amount of larval food $(150 \mu \mathrm{L})$ led to $78 \%$ of the queen's emergence, whereas larvae treated with $120 \mu \mathrm{L}$ and $100 \mu \mathrm{L}$ of larval food resulted in $40 \%$ and $0 \%$ of queen emergence. The dynamic survival curve showed that most of the larvae died before the pupation phase and reached constant stability afterward. The queen's body and abdominal length were significantly greater than wild workers. Microscopy analysis showed that in vitro queen had well-developed reproductive system with a huge ovary and spermatheca, whereas wild worker had much smaller ovary without spermatheca. Outcomes from this study could help increase the number of colonies on a large scale, allowing for their use both ecologically and economically, and contribute to conservation efforts in native species of stingless bees.
\end{abstract}

Keywords: Heterotrigona itama; Indo-Malayan stingless bee; in vitro rearing; larval food; queen

\section{ABSTRAK}

Permintaan untuk koloni kelulut di Malaysia meningkat dengan ketara disebabkan oleh perkembangan pesat meliponikultur yang menggunakan kelulut sebagai pendebunga pertanian dan pengkomersilan produk kelulut (i.e. madu, debunga lebah, propolis). Oleh itu, pembiakbakaan ratu in vitro dalam skala besar dan penggandaan koloni secara cepat perlu dilaksanakan untuk memenuhi permintaan awam dalam jangka masa yang pendek. Walau bagaimanapun, pengetahuan pembiakbakaan ratu kelulut Heterotrigona itama secara in vitro, masih tidak banyak diketahui. Oleh itu, dalam kajian ini, kami mengkaji jumlah makanan larva yang diperlukan oleh larva ratu kelulut $\mathrm{H}$. itama dengan membandingkan tiga jenis jumlah makanan larva iaitu $100 \mu \mathrm{L}, 120 \mu \mathrm{L}$ dan $150 \mu \mathrm{L}$. Ketiga-tiga rawatan dikawal di bawah kelembapan relatif $100 \%$ untuk 6 hari pertama dan $75 \%$ kelembapan relatif bagi keseluruhan pembesaran larva sehingga menjadi ratu dewasa dengan suhu $30^{\circ} \mathrm{C}$ di dalam inkubator. Keputusan menunjukkan larva $\mathrm{H}$. itama yang diberi dengan kuantiti makanan yang tertinggi (150 $\mu \mathrm{L})$ menyumbang kepada $78 \%$ penghasilan ratu, manakala larva yang dirawat dengan $120 \mu \mathrm{L}$ dan $100 \mu \mathrm{L}$ makanan larva menghasilkan 40\% dan 0\% ratu. Cerun kelangsungan hidup menunjukkan kebanyakan larva mati sebelum fasa pupa dan seterusnya mampu mencapai kestabilan malar. Badan dan panjang abdomen ratu adalah lebih besar secara signifikan berbanding pekerja liar. Analisis mikroskopi ratu in vitro menunjukkan ratu mempunyai sistem pembiakan yang lengkap dengan ovari yang besar berserta spermateka, manakala pekerja liar mempunyai ovari yang lebih kecil tanpa spermateka. Hasil daripada kajian ini dapat membantu untuk meningkatkan bilangan koloni berskala besar, supaya ia boleh dimanfaatkan untuk keperluan ekologi dan ekonomi, serta menyumbang kepada usaha pemeliharaan spesies kelulut asli.

Kata kunci: Heterotrigona itama; kelulut Indo-Malaya; makanan larva; pembelaan in vitro; ratu 


\section{INTRODUCTION}

Meliponiculture or stingless beekeeping has been recognized as one of the economical income to tropical and sub-tropical countries including Malaysia. Due to the increasing demand for stingless bee products, especially honey, propolis and bee bread, the meliponiculture activity is an emerging new source of income for many Malaysian beekeepers. Besides, meliponiculture has also been proven to increase crop yield and pollination by stingless bees which has also improved the quality of fruits (Azmi et al. 2019). Thus, meliponiculture is a highly lucrative activity that can help conserve endemic bee species for the bee products (honey, propolis, pollen) as well as promoting effective agricultural pollination which can allow beekeepers to work near native forests (dos Santos et al. 2016; Contrera et al. 2011; Slaa et al. 2006).

In Malaysia, a total of 45 species of stingless bees from 14 genera has been identified and documented (Rasmussen 2008; Samsudin et al. 2018). Out of that number, at least four species of Indo-Malayan stingless bees were locally domesticated in Malaysia including Heterotrigona itama, Geniotrigona thoracica, Tetragonilla atripes, and Tetrigona peninsularis (Mohd Norowi et al. 2008). However, meliponiculture faces major challenges, especially in multiplying the colonies. A recent study indicated that multiplying hives from the core colonies are often problematic, i.e. the core colonies hold only a few virgin queens (except Melipona Illiger) to help in successful colony multiplication (dos Santos et al. 2016). Multiplying colonies of stingless bees is not easy, requiring knowledge on the best timing to recognize and carefully extract the brood discs at the appropriate developmental stage. Moreover, newly multiplied colonies are usually weak and vulnerable to infestation by pests.

According to Department of Agriculture (2017), the total stingless bee honey production in Malaysia stood at $134,244 \mathrm{~kg}$ and generated total sales of RM19.3 million. However, the size of total honey production is still small compared to the market demand of approximately $802,962 \mathrm{~kg}$. Several strategies have been drawn to fulfil the market demand including importing the honey from abroad (Ismail \& Ismail 2018). This indicating the demand for honey has grown beyond the supplying capacity of beekeepers as the beekeepers are unable to control the honey production season as well as the mating behaviour of the stingless bees, which is season-dependent. Since the demand has increased extensively, an effort to multiply the number of stingless bee products rapidly must be developed to fulfil the public requirements of honey within a short period of time. This concern has led to an alternative technique to mass produce queen through in vitro queen rearing on a large scale. To date, there are few studies that have succeeded in colony increment by producing artificial queen of stingless bee in laboratory such as in vitro queen rearing of the Brazilian stingless bee species by Menezes et al. (2013).

In vitro method is a laboratory rearing technique that is conducted in a controlled laboratory setting which is more reliable because of all aspects (e.g. temperature, humidity, and light intensity) are administered at the required conditions (Kokich 2013). In addition, this in vitro rearing method benefits the multiplication or mass production of organisms for practical uses (Menezes et al. 2013). So far, limited studies have been reported on the rearing technology to increase the colonies number of the Indo-Malayan stingless bee species. Even though considerable studies have been conducted on the use of stingless bees as an effective pollinator for commercial crops pollination purposes (Azmi et al. 2017), however, to date, little attention has been made to study the technique of stingless bee rearing under laboratory conditions.

In most Trigona genera (including Heterotrigona spp.), the larva that are destined to become a queen is placed in a cell that is two or three times larger than worker brood cell at the edge, with a large amount of larval food portion. This has resulted in the development period for the queen being longer than that of workers, which explains why the brood cell of the queen is scattered around the brood chambers, apart from the remaining combs (Imperatriz-Fonseca \& Zucchi 1995). Overfeeding of the female larvae through in vitro rearing is a major contribution for the queen's emergence (Baptistella et al. 2012; dos Santos et al. 2016; Menezes et al. 2013) since the trophic factor is the only reliable element of caste determination in most of the stingless bee species (Hartfelder et al. 2006; Sakagami 1982).

In vitro technique for mass production of stingless bee queen has been applied to several species like Scaptotrigona depilis (Menezes et al. 2013), Plebeia droryana (dos Santos et al. 2016), and Frieseomelitta varia (Baptistella et al. 2012; Faustino et al. 2002). Camargo (1972) was the first to develop the technique of queen rearing under in vitro conditions with controlled humidity and temperature, based on the existing honeybee queen rearing method (Menezes et al. 2013). Initially, the experiment was conducted using S. postica and then extended to some other species by other researchers (Maciel-Silva \& Kerr 1991; Menezes et al. 2013). 
One of the most important factors in developing the in vitro rearing of eusocial stingless bees is related to the larvae's feeding process, which presents a strategy of mass food supply in their brood cells (Michener 2000). The mechanism of caste determination in most of the stingless bees is related to the amount of food ingested by the larvae during their development (Hartfelder et al. 2006). The larvae destined to become queens usually eat higher amount of larval food compared to larvae that will develop into workers (Engels \& Imperatriz-Fonseca 1990; Hartfelder et al. 2006). The queens develop in royal cells which are notably larger, formed from the junction of two equally sized brood cells, and the adjacent cell contains only the larval food (Faustino et al. 2002). Hence, during larval stage, the female stingless bee destined to become a queen will receive higher amount of semi-fluid food mass compared to female larvae that is destined to become workers (Kwapong et al. 2010).

Menezes et al. (2013) managed to produce $S$. depilis artificial queens similarly sized to a naturally produced queen. They achieved $97.9 \%$ of survival rate of the larvae and out of 50 introductions of artificial queen, 13 colonies had successfully established where the artificial queens were able to mate and lay eggs. Another species from Brazil, F. varia has also been tested to produce an in vitro queen where the researchers showed that the amount of larval food needed for the larvae to develop as a queen was 2.31 times more than the workers ingested during the larval stage (Baptistella et al. 2012). As such, an attempt on manipulation of larval feeding to artificially produce queens is particularly important in understanding the basic mechanisms of caste determination in stingless bee in vitro rearing.

Hence, the objective of this study was to determine the effect of larval food on the in vitro rearing of the IndoMalayan stingless bee queen Heterotrigona itama, one of the most domesticated stingless bee species in Malaysia, with some modification of the previous research. The experiment highlighted the manipulation of larval food amounts on each cell in Elisa plate, in which all the treatments were placed in similarly controlled humidity and temperature in the incubator.

\section{Materials AND Methods}

\section{SAMPLE COLLECTION}

The eggs of $H$. itama and larval fluid were collected from stingless bee colonies in Big Bee Honey Apiary and Universiti Malaysia Terengganu (UMT) Bukit Kor Campus, both situated in Marang district, Terengganu, Malaysia. The in vitro queen rearing was conducted in
Central Laboratory, UMT. Around 300-500 brood cells of the newly constructed brood combs were harvested to collect sufficient amount of larval food for queen rearing. In order to prevent major destruction of the colonies, we garnered about two to three layers of the newly emerged brood cells and ignored the matured brood cells. The newly constructed brood cells are generally dark brown in colour and after reaching pupation they turn into lighter colour or pale due to scraping of cerumen by workers which varies in pigmentation depending upon their age. The young brood cells were selected because they contained eggs or young larvae with higher amount of semi-fluid food mass. Whereas, the older brood cells were ignored because the cells contained old larvae with little amount of larval food.

The recently built brood cells were taken out of the rearing box gently using knife and scalpel to avoid massive destruction to the colonies. The brood cells then were kept in clean containers $(19.8 \times 19.8 \times$ $7.0 \mathrm{~cm}$ ) in darkness to minimize potential exposure to microorganisms and dispatched to the laboratory on the day they were collected. We also excluded queen cells allocated separately on the edge of the brood combs to prevent excessive damage to the colonies.

\section{EXTRACTION OF EGGS AND LARVAL FOOD}

The brood cells top was opened using a small needle to obtain the larval food and egg. The eggs were taken out carefully from the brood combs using a sterilized needle. The brood combs were squeezed into a $50 \mathrm{~mL}$ centrifuge tube to get the larval food liquid. Each ELISA plate was filled with the larval food using Eppendorf Research ${ }^{\circledR}$ Plus micropipette $(1000 \mu \mathrm{L})$. In this treatment, we tested on $100 \mu \mathrm{L}$ (act as control), $120 \mu \mathrm{L}$, and $150 \mu \mathrm{L}$ of larval food on $H$. itama larvae, to ascertain the amount of larval food responsible for producing queens with a size similar to the queen produced naturally. This is based on our hypothesis and Baptistella et al. (2012) that the larvae destined to become queens receive double the amount of larval food in the royal cells than larvae destined to become workers which are reared in smaller brood cells. All the treatments received homogenous humidity (100\% during the first 7 days and $75 \%$ for the rest of larval development) and room temperature $\left(25 \pm 2.5^{\circ} \mathrm{C}\right)$. The experiment was conducted with 10 eggs per replicate and five replications per treatment $(\mathrm{N}=150)$.

\section{QUEEN REARING PROCEDURE}

When placing the larvae into the Elisa plate with 96 cavities, it is important to consider the most crucial steps 
throughout the grafting procedures, as they determine the success of the overall queen development. In the laboratory, using a small-sized tool with a V-shaped tip, the eggs were placed in the ELISA plate vertically. In order to ensure the survival rate of the eggs, it was important to place them in a vertically as they are deposited in natural brood cells, to prevent them dying from asphyxiation due to blocking of airflow through their spiracles (dos Santos et al. 2016). The extraction of eggs was done in a biological safety cabinet, whereas the queen rearing experiment was done in an incubator (Model: Rcom Reptile MAX 60). In order to prevent the larval food from drying out, a moist cloth was kept beneath the frame to increase humidity around $80 \%$ to $100 \%$.

Throughout the larval development, humidity in the incubator was kept under control at $100 \%$ during the first seven days and $75 \%$ during the rest of the larval development, by using pure water and saturated salt solution, sodium chloride $(\mathrm{NaCl})$, respectively. Saturated salt solutions are more effective in maintaining a consistent humidity in environment than other concentrated substances such as potassium hydroxide $(\mathrm{KOH})$, and sulfuric acid $\left(\mathrm{H}_{2} \mathrm{SO}_{4}\right)$ (Solomon 1951; Winston \& Bates 1960). The relative humidity in the incubator was continuously checked to ensure the required humidity value in controlled by using a Hygrometer (Thermo Hygro Anemometer 3 in 1). It is crucial to reduce the humidity to $75 \%$ to prevent water evaporation in the Elisa plate, which is responsible for their high mortality rate.

\section{MICROSCOPY ANALYSIS OF REPRODUCTIVE SYSTEM BETWEEN in vitro QUEENS AND WILD WORKERS OF H. itama}

In order to verify that the adult queen is produced under in vitro condition, we compared the reproductive system of the in vitro queen to the wild workers of $H$. itama which were randomly chosen from the apiaries. Fresh samples of in vitro queen and wild workers were placed in a plastic-mesh cage $(17 \times 12 \times 7 \mathrm{~cm})$. The samples were then fixed in Phosphate Buffer Solution (PBS: 136.9 Mm NaCl, 8.1 $\mathrm{Mm} \mathrm{Na}_{2} \mathrm{HPO}_{4}, 2.7 \mathrm{Mm} \mathrm{KH}_{2} \mathrm{PO}_{4}$ ) with pH 7.1 to prevent major organ dryness. The dissection was done using micro dissecting kit under stereo microscope of Carl Zeiss (V12). The reproductive systems were stained with several drops of Methylene blue solution to differentiate organ structure. Immediately after fixation, the reproductive systems were observed and photographed using Olympus BX-60 microscope. We also randomly chose workers from the apiaries and performed the body and abdomen measurement from the head top until abdomen tips and metasoma abdomen section, respectively. We have to exclude the wild queens in this analysis to prevent major collapses to the colonies, which is one of the major problems in our beekeeping industry.

\section{STATISTICAL ANALYSIS}

In order to determine the significant difference between three treatments tested in response to the caste emergence (queens vs. worker), we first employed a Normality test. Since the data were non-parametric, we used the Kruskal-Wallis test to compare the significant value between the three treatments $100 \mu \mathrm{L}, 120 \mu \mathrm{L}$, and $150 \mu \mathrm{L}$ of larval food that contributed to the caste emergence. We used T-test to compare the differences between body and abdominal lengths of both in vitro queens and wild workers. All statistical analyses were conducted using statistical software analysis of SPSS version 21.0.

\section{RESULTS AND DISCUSSION}

The three different amounts of larval food were selected after we measured the volume of larval food from several new brood cells of $H$. itama workers $(50.4 \pm 1.22 \mu \mathrm{l}$; $\mathrm{N}=20$ ) retained from the UMT meliponiary. Then, we double and triple multiplied the amount of larval food as suggested by Baptistella et al. (2012) who reported that the larvae destined to become queens receive two to three times larger amount of larval food than larvae destined to become workers.

In this study, 59 in vitro queens of $H$. itama were successfully produced. The amounts of larval food provided in each cell of the ELISA plate in response to the caste emergence were significantly different (KruskalWallis $=79.184, d f=2, P<0.001)$. The eggs treated with the highest larval food amount $(150 \mu \mathrm{L})$ resulted to the total of $78 \%$ queen emergence (39 individuals). The lowest amount of larval food $(100 \mu \mathrm{L})$ produced solely 39 worker individuals ( $78 \%$ worker emergence) (Figure 1). The result somehow showed both emergence of worker (8\%) and queen (40\%) in a $120 \mu \mathrm{L}$ of larval food treatment, but most of the larvae died in that treatment (52\%) (Figure 1).

The larval survival dynamics for all treatments (100 $\mu \mathrm{L}, 120 \mu \mathrm{L}$, and $150 \mu \mathrm{L}$ of larval food) showed steep initial decline during the first five weeks after rearing, although the degree of this decease varied considerably among individuals (Figure 2). Nonetheless, the individuals showed survival stability afterward. In a cell containing $150 \mu \mathrm{L}$, we observed that some of the larval food remained unconsumed. The larvae were unable 
to ingest more than $150 \mu \mathrm{L}$ of larval food, which resulted in high mortality rates before the pupation stage. However, their mortality could be due to many factors. According to Baptistella et al. (2012), changing the relative humidity in the incubator is one of the contributory factors for their high mortality rate during their first experiment. We observed that the critical stage of H. itama larvae was before the pupation stage, which required continuous inspection until the pupation stage. In certain cases, the larval food could possibly contribute to the high mortality rate, due to the excessive amount of microorganism in the larval food (Baptistella et al. 2012).

Despite indisputable differences in patterns of survival growth curve, the treatment with the highest quantum of larval food $(150 \mu \mathrm{L})$ emerged as a total queen adult, the group somehow required extensive time to completely emerge into adult queen, which is approximately 50 to 56 days. It was completely different from the larvae treated with $100 \mu \mathrm{L}$ with $78 \%$ of worker emergence, which required approximately 40 and 47 days of developmental growth. However, individual treated with $120 \mu$ l of larval food both resulted in worker and queen castes at different emergence period. Four worker individuals in $120 \mu \mathrm{L}$ of larval food might be resulted from inadequate larval food consumption. This probably because of the different level of larval food consumption activity. Thus, it could be suggested that the larval period for queen of H. itama is longer, compared to workers of $H$. itama.

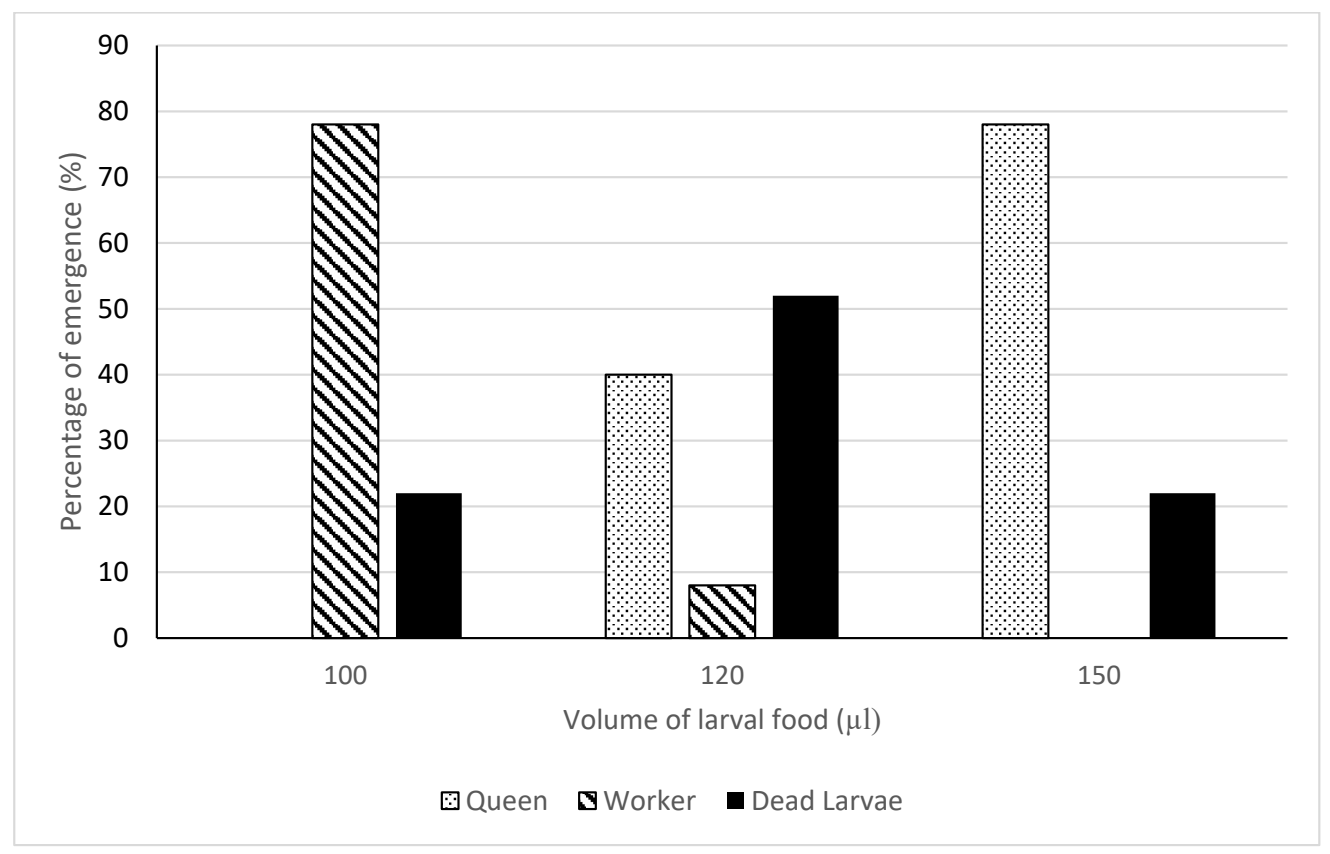

FIGURE 1. The percentage of worker and queen emergence in respond to three different larval food treatments from the in vitro rearing experiment $(\mathrm{N}=150)$

From this study, different quantities of larval food have resulted in different development of reproductive systems between workers and queens, due to the different levels of ingestion of larval food. The queen's reproductive system of $150 \mu \mathrm{L}$ larval food was obviously different from those of workers. The queen's ovary size was twice as large than individual workers (Figure 3). The in vitro queen possessed a completely developed ovary structure that is contrary to the ovary structure of wild workers. The wild workers appeared either having a small or without ovary, with little number of ovarioles inside. Interestingly, one huge difference between the two castes was the spermatheca structure where it was only fully developed in the in vitro queen ovary which is connected with similar oviduct by spermathecal duct (Figure 4). However, there was no spermatheca observed in the dissected wild workers of H. itama.

The queens' body and abdominal size from treatment of $150 \mu \mathrm{L}$ larval food were completely different with worker size. Queen size was based on the physical appearance that appeared two times larger 


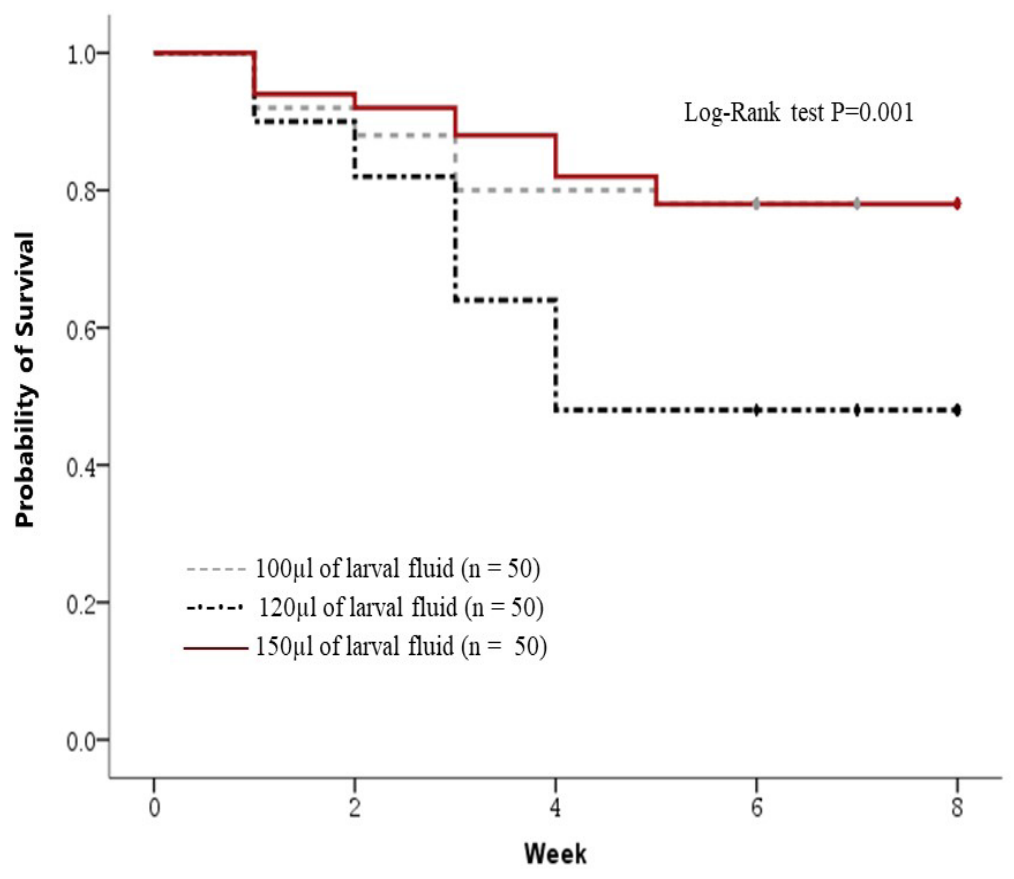

FIGURE 2. The Kaplan-Meier plot of the larval survival for 8 weeks observation in respond to three different larval food treatments

than worker individual. The queen abdominal lengths were significantly longer $(4.24 \pm 0.01 \mathrm{~mm})$ compared to worker $(1.55 \pm 0.009 \mathrm{~mm})\left(\mathrm{t}_{(10)}=-481.677, p<0.000\right)$. Similarly, the queen body lengths were significantly greater $(8.73 \pm 0.04 \mathrm{~mm})$ than workers $(6.17 \pm 0.04 \mathrm{~mm})$ $(t=-104.531, \mathrm{df}=10, p<0.001)$.

Higher quantum of larval food consumption is the main contributor that leads to the queen's emergence. In this study, the designed experiment successfully produced 59 in vitro queens of $H$. itama, tested on different quantities of larval food along 56 days of rearing, from the egg up to the adult queen phase, in an incubator with a similar humidity control for each treatment. The amount of food ingested by larvae during their development is an important causal factor for caste induction in most of the stingless bee population (Baptistella et al. 2012; Hartfelder et al. 2006; Wheeler 1986). Besides, this element has also delayed the adult emergence throughout their development, due to overfeeding.

These results showed a great difference between naturally-produced workers and in vitro queens. To verify whether the artificially produced adult is a queen, we concentrated on the anatomy of reproductive systems between the in vitro queen and naturally produced worker bees, which is considered a reliable method by
Hartfelder et al. (2006). The ovary size and occurrence of spermatheca were the parameters used in this observation to differentiate between wild workers and artificially produced queens, to conclusively verify that the emerged adult was a queen. This study showed that in vitro produced queens from treatment of $150 \mu \mathrm{L}$ twice large as wild workers, with a huge abdomen that had well-developed reproductive system, with a huge ovary with many ovarian filaments (ovarioles) and a spermatheca, which increase the possibility of queens to lay eggs (Figures $3 \& 4$ ).

In contrast, workers of $H$. itama also have ovaries but without spermatheca, and the ovary size is much reduced with little number of ovarioles compared to those of the in vitro queen. In Meliponinae, workers always have shorter ovaries which consisted of four ovarioles in each ovary and developed differently depending on species (Cruz-Landim 2000). Ovaries appearance in workers is determined by factors acting in pupation stage because early larvae were sorted with normal ovaries beforehand (Cruz-Landim 2000). The number of ovarioles varies in each species. For examples, Melipona quadrifasciata anthidioides queen have four ovarioles per ovary, and about a dozen in Trigona spinipes. Further ultrastructural study should be done to verify the ovariole number in the in vitro $H$. itama queen and workers. In this 
study, we did not inspect the naturally- produced queen reproductive system to prevent the colonies from facing high disturbance as well as to sustain that population. It was somehow relatable with the reproductive system of wild workers that acted as a benchmark for caste differentiation. However, the newly-emerged in vitro bees were not yet being influenced by social behavior, which might naturally force the internal changes of the gene expression right after they interact with their habitual colony (Hartfelder et al. 2006).

Mass production of queens under in vitro condition has created a considerably great and practical platform in the last several years (Baptistella et al. 2012; dos Santos et al. 2016; Menezes et al. 2013). The current status of the stingless bee population of some species makes it relevant to apply the in vitro technique widely, which would increase the number of queens produced, thus increasing the number of new colonies emerging, which in turn can significantly increase the number of bees rapidly through multiplication of colonies (dos Santos et al. 2016). Thus, this effort will continue to investigate the fertility and fecundity rate of in vitro queens.

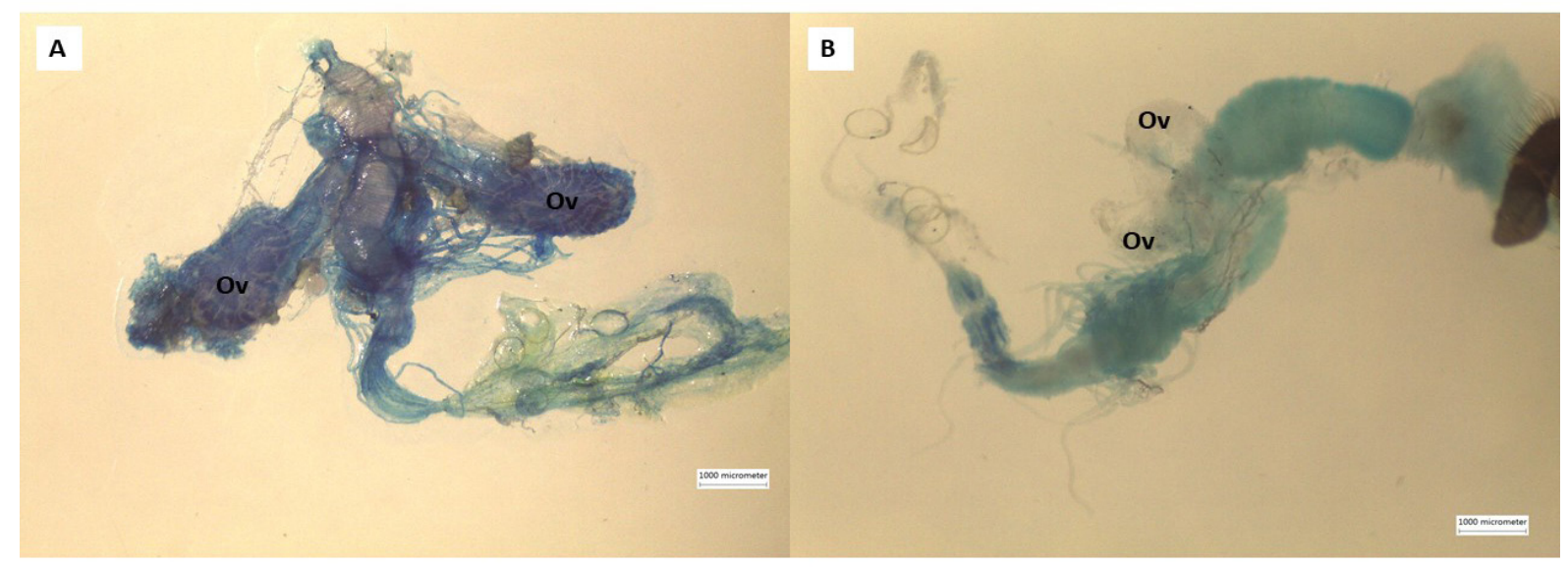

FIGURE 3. Microscopy images of gonadal development in H. itama (A) Freshly dissected reproductive system of in vitro queen of $H$. itama with well-developed ovarioles structure, (B) Dissection figure of $H$. itama workers showed huge different of ovarioles size compared to in vitro queen (Ov, ovary)

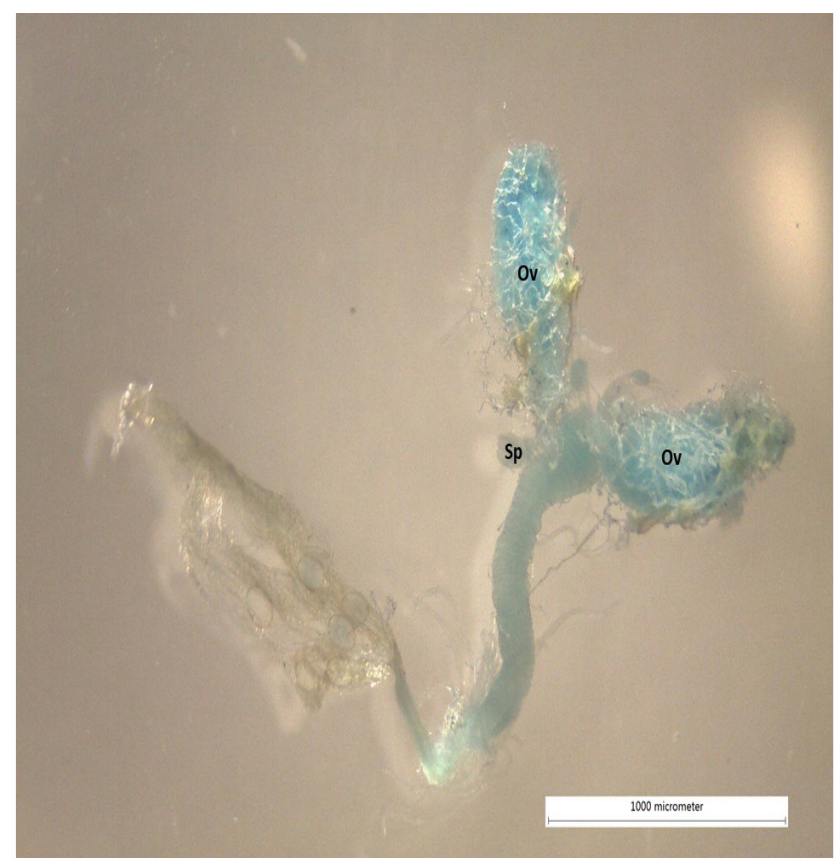

FIGURE 4. H. itama in vitro queen reproductive system. The ovaries $(\mathrm{Ov})$ built in with follicles connected to the lateral oviducts. The arrow exhibited spermatheca $(\mathrm{Sp})$ connected to the similar oviducts. No spermatheca was observed in H. itama workers (Ov, ovary; Sp, spermatheca) 


\section{CONCLUSION}

This study shows that greater quantity of larval food $(120 \mu \mathrm{L}$ to $150 \mu \mathrm{L})$ had transformed the eggs of H. itama into queens. Larvae treated with $150 \mu \mathrm{L}$ were twice larger than wild workers, with a huge abdomen that had well-developed reproductive system with a huge ovary and spermatheca for mating purpose. The high mortality rate under in vitro condition is common and need to be further investigated. Thus, more studies could be done to clarify the queen caste emergence mechanism and the causes of high mortality rate of the eggs. The current study is designed to help the stingless beekeepers to multiply the colonies in a short period of time. This is a new technique to produce a massive stingless bee queens under in vitro conditions. Implying this technique can significantly increase the colonies emergence, thus, increase beekeepers and agronomist economical values.

\section{ACKNOWLEDGEMENTS}

We would like to thank the Ministry of Higher Education (MOHE), Malaysia for providing the financial support through the Fundamental Research Grant Scheme (FRGS) (VOT: 59496), Faculty of Science and Marine Environment and Central Laboratory at Universiti Malaysia Terengganu for the research facilities, Big Bee Honey Farm and Taman Penyelidikan Alam Universiti Malaysia Terengganu in Marang, Terengganu for the sampling provided, Dr. Cristiano Menezes from Brazilian Agricultural Research Corporation (EMBRAPA) and Mr. Fahimee Jaapar from Malaysian Agricultural and Research Development Institute (MARDI) for unstintingly sharing their knowledge and experience in in vitro rearing of stingless bees.

\section{REFERENCES}

Azmi, W.A., Wan Sembok, W.Z., Yusuf, N., Mohd. Hatta, M.F., Salleh, A.F., Hamzah, M.A.H., \& Ramli, S.N. 2019. Effects of pollination by the Indo-Malaya stingless bee (Hymenoptera: Apidae) on the quality of greenhouse-produced rockmelon. Journal of Economic Entomology 112(1): 20-24.

Azmi, W.A., Samsuri, N., Hatta, M.F.M., Ghazi, R. \& Seng, C.T. 2017. Effects of stingless bee (Heterotrigona itama) pollination on greenhouse cucumber (Cucumis sativus). Malaysian Applied Biology 46(1): 51-55.

Baptistella, A.R., Souza, C.C., Santana, W.C. \& Soares, A.E.E. 2012. Techniques for the in vitro production of queens in stingless bees (Apidae, Meliponini). Sociobiology 59(1): 297-310.
Camargo, C.D. 1972. Determinação de castas em Scaptotrigona postica Latreille (Hymenoptera, Apidae). Revista Brasileira de Biologia. 32(1): 133-138.

Contrera, F.A.L., Menezes, C. \& Venturieri, G.C. 2011. New horizons on stingless beekeeping (Apidae, Meliponini). Revista Brasileira de Zootecnia 40: 48-51.

Cruz-Landim, C.D. 2000. Ovarian development in Meliponine bees (Hymenoptera: Apidae): The effect of queen presence and food on worker ovary development and egg production. Genetics and Molecular Biology 23(1): 83-88.

Department of Agriculture. 2017. Statistics of Stingless Beekeepers in Malaysia. Putrajaya: Ministry of Agriculture of Malaysia.

dos Santos, C.F., dos Santos, P.D.D.S. \& Blochtein, B. 2016. In vitro rearing of stingless bee queens and their acceptance rate into colonies. Apidologie 47(4): 539-547.

Engels, W. \& Imperatriz-Fonseca, V.L. 1990. Caste development, reproductive strategies and control of fertility in honey bees and stingless bees. In Social Insects, edited by Engels, W. Berlin, Germany: Springer-Verlag. pp. 167230.

Faustino, C.D., Silva-Matos, E.V., Mateus, S. \& Zucchi, R. 2002. First record of emergency queen rearing in stingless bees (Hymenoptera, Apinae, Meliponini). Insectes Sociaux 49(2): 111-113.

Hartfelder, K., Makert, G.R., Judice, C.C., Pereira, G.A., Santana, W.C., Dallacqua, R. \& Bitondi, M.M. 2006. Physiological and genetic mechanisms underlying caste development, reproduction and division of labor in stingless bees. Apidologie 37(2): 144-163.

Imperatriz-Fonseca, V.L. \& Zucchi, R. 1995. Virgin queens in stingless bee (Apidae, Meliponinae) colonies: A review. Apidologie 26(3): 231-244.

Ismail, M.M. \& Ismail, W.I.W. 2018. Development of stingless beekeeping projects in Malaysia. E3S Web of Conferences 52: 00028

Kokich, V.G. 2013. In-vitro vs in-vivo materials research. American Journal of Orthodontics and Dentofacial Orthopedics 143(4): S11.

Kwapong, P., Aidoo, K., Combey, R. \& Karikari, A. 2010. Stingless Bees - Importance, Management and Utilization: A Training Manual for Stingless Beekeeping. Accra, Ghana: Unimax Macmillan Ltd. p. 72.

Maciel-Silva, V.L. \& Kerr, W.E. 1991. Sex determination in bees. XXVII. Castes obtained from larvae fed homogenized food in Melipona compressipes (Hymenoptera, Apidae). Apidologie 22(1): 15-19.

Menezes, C., Vollet-Neto, A. \& Fonseca, V.L.I. 2013. An advance in the in vitro rearing of stingless bee queens. Apidologie 44(5): 491-500.

Michener, C.D. 2000. The Bees of the World. London: The Johns Hopkins University Press. p. 913.

Mohd Norowi, H., Sajap, A.S., Rosliza, J., Mohd Fahimie, J. \& Suri, R. 2008. Conservation and sustainable utilization of stingless bees for pollination services in agricultural ecosystems in Malaysia. Putrajaya: Department of Agriculture. p. 12. 
Rasmussen, C. 2008. Catalog of the Indo-Malayan/Australasian stingless bees (Hymenoptera: Apidae: Meliponini). Auckland: Magnolia Press. pp. 15-17.

Sakagami, S.F. 1982. Stingless bees. In Social Insects. Vol. III, edited by Hermann, H. New York: Academic Press. pp. 361-423.

Samsudin, S.F., Mamat, M.R. \& Hazmi, I.R. 2018. Taxonomic study on selected species of stingless bee (Hymenoptera: Apidae: Meliponini) in Peninsular Malaysia. Serangga 23(2): 2013-258.

Slaa, E.J., Chaves, L.A.S., Malagodi-Braga, K.S. \& Hofstede, F.E. 2006. Stingless bees in applied pollination: Practice and perspectives. Apidologie 37(2): 293-315.

Solomon, M.E. 1951. Control of humidity with potassium hydroxide, sulphuric acid, or other solutions. Bulletin of Entomological Research 42(3): 543-554.

Wheeler, D.E. 1986. Developmental and physiological determinants of caste in social Hymenoptera: Evolutionary implications. The American Naturalist 128(1): 13-34.

Winston, P.W. \& Bates, D.H. 1960. Saturated solutions for the control of humidity in biological research. Ecology 41(1): 232-237.

Nurul Izdihar Razali, Fatimah Hashim \& Wahizatul Afzan Azmi*

Faculty of Science and Marine Environment

Universiti Malaysia Terengganu

21030 Kuala Nerus, Terengganu Darul Iman

Malaysia
Shamsul Bahri Abd Razak

Faculty of Fishery and Food Science

Universiti Malaysia Terengganu

21030 Kuala Nerus, Terengganu Darul Iman

Malaysia

Nurul Wahida Othman

Department of Biological Sciences and Biotechnology

Faculty of Science and Technology

Universiti Kebangsaan Malaysia

43600 UKM Bangi, Selangor Darul Ehsan

Malaysia

Wahizatul Afzan Azmi*

Institute of Tropical Biodiversity and Sustainability

Development

Universiti Malaysia Terengganu

21030 Kuala Nerus, Terengganu Darul Iman

Malaysia

*Corresponding author; email: wahizatul@umt.edu.my

Received: 17 August 2020

Accepted: 22 February 2021 